\title{
Sugarcane spirit market share simulation: an application of conjoint analysis
}

\author{
Simulação do mercado de cachaça: uma aplicação da análise conjunta de fatores
}

\author{
João de Deus Souza CARNEIRO ${ }^{1}$, Valéria Paula Rodrigues MINIM ${ }^{2 \star}$, Carlos Henrique Osorio SILVA³, \\ Adair José REGAZZI ${ }^{3}$, José Benicio Paes CHAVES ${ }^{2}$, Luis Antonio MINIM ${ }^{2}$
}

\begin{abstract}
This study evaluated the influence of packaging and labeling attributes of sugarcane spirit on consumers' behavior by applying the results of conjoint analysis in sugarcane spirit market share simulation. Firstly, a conjoint analysis was performed aiming to estimate the part-worths of each consumer for some sugarcane spirit packaging and labeling attributes. These part-worths were used in the market share simulation using the maximum utility model. It was observed that some packaging and labeling attributes affected consumer's purchase intention and that most consumers showed a similar preference pattern regarding these attributes. These consumers showed preference for the Seleta brand, which was bottled in $700 \mathrm{~mL}$ clear glass bottles with a metal screw cap that bore a label illustration unrelated to sugarcane spirit production process and had the information "aged 36 months in oak barrels". This study also showed that conjoint analysis and the use of its results in the market share simulation proved important tools to better understand consumer behavior towards intention to purchase sugarcane spirit. Keywords: conjoint analysis; sugarcane spirit; behavior; consumer; packaging.
\end{abstract}

\section{Resumo}

Este trabalho avaliou a influência de alguns fatores da embalagem e do rótulo de cachaça no comportamento dos consumidores, por meio da aplicação dos resultados da análise conjunta de fatores na simulação do mercado de cachaça. Inicialmente, realizou-se a análise conjunta de fatores, objetivando-se estimar os coeficientes da preferência dos consumidores em relação a alguns fatores da embalagem e do rótulo de cachaça. Esses coeficientes da preferência dos consumidores foram usados na simulação da participação de mercado, utilizando-se o modelo da máxima utilidade. Observou-se que os fatores da embalagem e do rótulo influenciaram na intenção de compra dos consumidores, sendo que os consumidores apresentaram preferência semelhante em relação a esses fatores. Esses consumidores preferiram as cachaças da marca Seleta, acondicionadas na garrafa de vidro transparente com capacidade igual a $700 \mathrm{~mL}$ e com tampa metálica rosqueável, que traziam no rótulo ilustração não relacionada ao processo produtivo de cachaça e a informação "envelhecida por 36 meses em tonéis de carvalho". Verificou-se, também, que a técnica análise conjunta de fatores e a aplicação dos seus resultados na simulação da participação de mercado foram ferramentas úteis no entendimento do comportamento dos consumidores de cachaça.

Palavras-chave: análise conjunta de fatores; cachaça; comportamento; consumidor; embalagem.

\section{Introduction}

Sugarcane spirit has been produced since 1536, and it has a central role in the Brazilian agribusiness. There are currently about 5,000 different brands and 30,000 manufacturers in Brazil, where around 1.3 billion liters are consumed annually. Moreover, sugarcane spirit export has grown by $10 \%$ a year, reaching an export volume of 15 million liters (ASSOCIAÇÃO..., 2012).

Several studies have been conducted aiming at improving the quality and value of the sugarcane spirit Cantão (2006), Abreu-Lima, Maia and Oliveira (2005), Lima (2005), Yokota (2002, 2005), Aguiar (2003), Jeronimo, Cardello and Serra (2004), Faria et al. (2003), Mori et al. (2003), Cardello and Faria (2000), Oliveira (2000), Cardello and Faria (1998) and Furtado (1995). However, there are no studies on the behavior of consumers of sugarcane spirit, i.e., studies to identify the factors that influence purchase and consumption of this product.
Conjoint analysis is one of the techniques that can be used to assess consumer behavior. This technique aims to understand how consumers develop preferences for products or services, and it is based on the premise that they evaluate the value or usefulness of a product or service by combining the value or usefulness of features that make up an individual product or service (HAIR JUNIOR et al., 1998).

In recent years, several Brazilian researchers, Kimura et al. (2011), Della Lucia et al. (2011), Mesias et al. (2011), Deliza et al. (2010), Reis (2007), Della Lucia (2005), Souza et al. (2004), Carneiro (2002), Dantas (2001), Costa (1999) and Deliza (1996), have used this technique to study the influence of the packaging, labeling, or the product itself on the behavior of consumers of soy based fermented products, light strawberry yogurt, functional and organic eggs, irradiated fruits, yogurt,

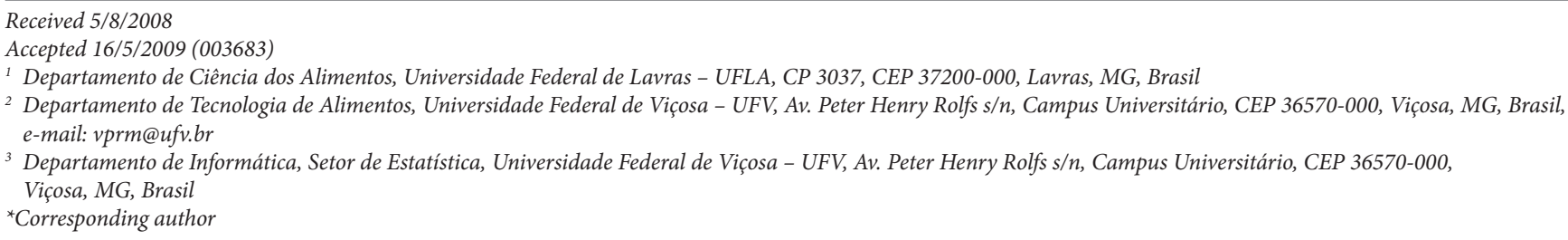


organic coffee, soybean oil, minimally processed wild cabbage, sunflower oil, and passion fruit juice, respectively.

According to Millher et al. (1998), conjoint analysis can be used in market share simulation and segmentation, and in new product development, and to assess advertisement appeal. When the goal is market share simulation, the part-worths estimated in the conjoint analysis are used to simulate market share of products

Due to the importance of sugarcane spirit agribusiness in Brazil, to recent changes in the sector, and to the need to obtain information about the behavior of consumers of sugarcane spirit, this study evaluated the influence of packaging and labeling attributes on consumers' behavior by applying the results of conjoint analysis in sugarcane spirit market share simulation. The objective was to obtain detailed information about the behavior of sugarcane spirit consumers to help producers to design and/or change packages and labels and develop marketing strategies.

\section{Materials and methods}

\subsection{Conjoint analysis}

Firstly, a conjoint analysis was performed aiming to estimate the influence of packaging and labeling attribute levels (part-worths) on the purchase intention of sugarcane spirit consumers.

\section{Definition of attributes and their levels}

The attributes and levels were defined using focus group research. The attributes and levels that influence the most the process of choosing and purchasing of the focus group's participants were selected. Hence, five sugarcane spirit packaging and labeling attributes with two levels each were evaluated With regard to the attribute brand name, the brand Seleta was chosen because it is well known by consumers in the market segment evaluated, and the brand Abaíra was chosen for being little known in this segment (Chart 1).

Chart 1. Selected attributes and their respective levels.

\begin{tabular}{|l|l|}
\hline \multicolumn{1}{|c|}{ Attributes } & \multicolumn{1}{c|}{ Levels } \\
\hline $\begin{array}{l}\text { Type of wood } \\
\text { barrel }\end{array}$ & $\begin{array}{l}\text { 1-Oak } \\
\text { 2-Umburana }\end{array}$ \\
\hline Aging time & $\begin{array}{l}1-18 \text { months } \\
2-36 \text { months }\end{array}$ \\
\hline Brand name & $\begin{array}{l}\text { 1-Abaíra } \\
\text { 2-Seleta }\end{array}$ \\
\hline $\begin{array}{l}\text { Label } \\
\text { illustration }\end{array}$ & $\begin{array}{l}\text { 1-Related to sugarcane spirit production process } \\
\text { 2-Unrelated to sugarcane spirit production process }\end{array}$ \\
\hline $\begin{array}{l}\text { Type of } \\
\text { packaging }\end{array}$ & $\begin{array}{l}\text { 1-Bottle 1 } \\
(700 \mathrm{~mL} \text { clear glass bottles with a metal screw cap })\end{array}$ \\
& $\begin{array}{l}\text { 2-Bottle 2 } \\
(600 \mathrm{~mL} \text { amber glass bottles with a metal crown cap) }\end{array}$ \\
\hline
\end{tabular}

*Illustration showing alembic still, barrels, and sugarcane fields. ${ }^{* *}$ Illustration showing three people sitting around a table, drinking sugarcane spirit, and playing musical instruments (samba ensemble).

\section{Data collection and experimental design}

The method of data collection was the full profile approach (GREEN; SRINIVASAN, 1978). In this method, each treatment is formed by the combination of all attributes, which consists of one level of each factor.

By combining the attribute levels using a complete factorial design, 32 treatments were obtained. However, this number of treatments could lead to respondent fatigue during the assessment of purchase intention. Therefore, a fractional factorial design, consisting of a subset of 8 treatments (Chart 2) was chosen; i.e., one-quarter fraction of the 32-treatment design. This fractional factorial was selected using the PROC OPTEX SAS (version 9.0, licensed for UFV 2008). The 8 treatments selected to form a fraction of the full factorial design were established so that all the major effects of the five attributes (type of wood barrel, aging time, brand name, label illustration, and type of packaging), were estimable. That is, no interaction between the attributes was considered in the model. It is noteworthy that 144 evaluations were collected for each treatment (see below in 2.1.4); hence, there were sufficient degrees of freedom to estimate the part-worths needed in the conjoint analysis.

\section{Treatment development}

Eight labels were designed according to the descriptions of treatments (Chart 2) using the CorelDRAW Software following the labeling requirements for foods and beverages. These labels were printed on sticker paper and adhered to eight sugarcane spirit bottles: $700 \mathrm{~mL}$ clear glass bottles with a metal screw cap (bottle 1) and $600 \mathrm{~mL}$ amber glass bottles with a metal crown cap (bottle 2). Figure 1 shows, two treatments evaluated. It is worth mentioning that the eight bottles contained exactly the same sugarcane spirit, i.e., there was no difference between the beverages added to the bottles

\section{Treatment evaluation}

The treatments were evaluated by 144 attendants of the $76^{\text {th }}$ Farmer Week, held in the city of Viçosa, MG. These participants were used to consume sugarcane spirit at least once a month and had the habit of reading bottle labels. The number of consumers was determined according to the experimental design chosen for the evaluation of treatments.

The eight treatments were evaluated for purchase intention in individual booths using an unstructured scale (CARNEIRO; SILVA; MINIM, 2010). This scale consisted of a 9-cm horizontal line anchored at opposite ends with the expressions "definitely not buy" and "definitely buy".

Prior to the evaluation, consumers were informed about the test procedure and asked to behave as if they were in a shop buying sugarcane spirit (simulation of purchase). The treatments were coded with a three-digit number and were presented monadically with no time restriction, in the same session, to each consumer. The order of presentation of treatments was arranged according to the experimental design for evaluating treatments proposed by MacFie et al. (1989). According to this design, each treatment appeared in a given position an equal number of times and was preceded by the others the 
Chart 2. Treatments evaluated.

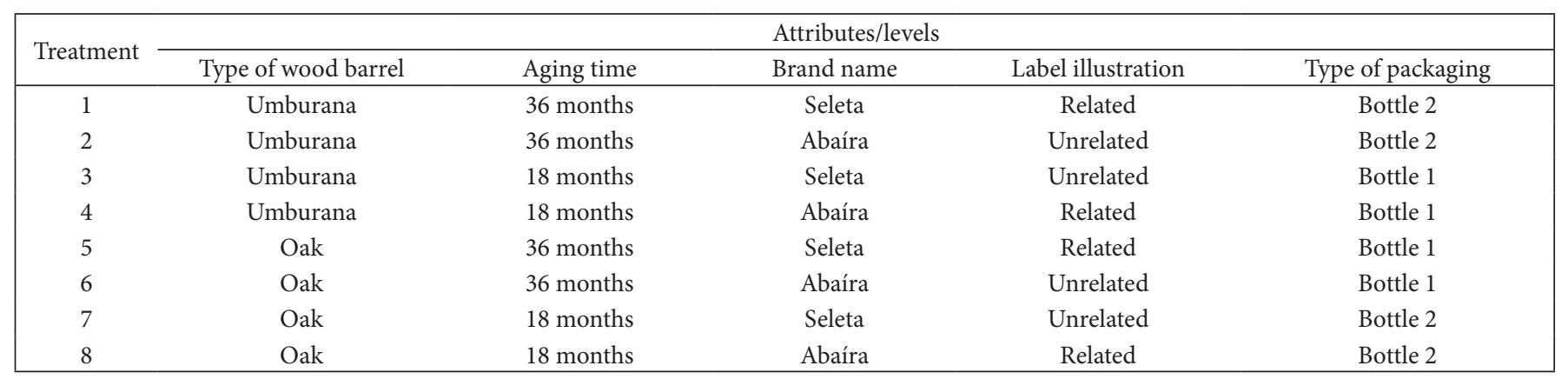

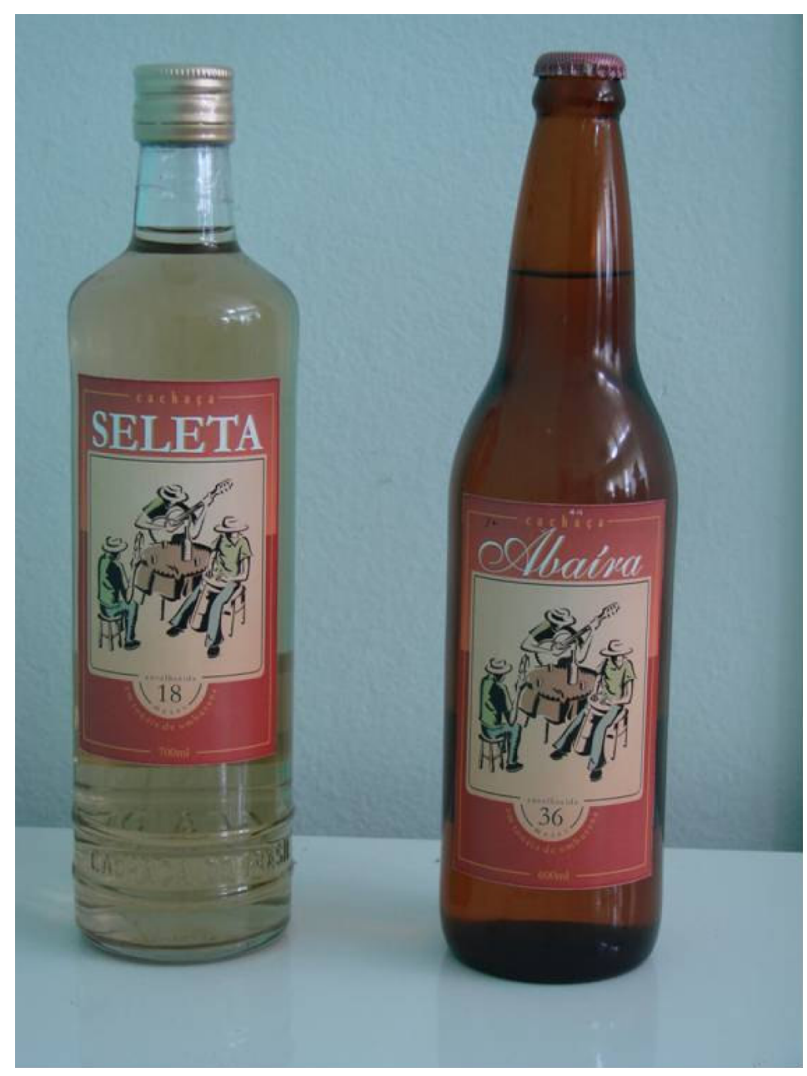

Figure 1. Examples of treatments used in this study.

same number of times, thus preventing order of presentation and carryover effects. Carryover effect is the influence of one treatment on the next evaluation. The selected design contained 48 different sequences of treatment presentation, which is a sufficient number to estimate the five major effects (type of wood barrel, aging time, brand name, label illustration, and type of packaging $)$ in a non-biased way. Three replicates $(3 \times 48=144$ consumers) were used.

\section{Data analysis}

The consumer purchase intention responses were transformed into scores and were tabulated in a double entry table representing consumers versus treatments.
Data analysis was performed using the additive model as the composition rule. This model assumes that the global preference evaluations are formed by the sum of the part-worths (STEENKAMP, 1987). The general form of the additive model for $\mathrm{n}$ factors, each one with $\mathrm{m}_{\mathrm{i}}$ levels, is given by:

$U_{c k}=\sum_{i=1}^{n} \sum_{j=1}^{m_{i}} C P_{i j} X_{i j}^{k}+\varepsilon_{c k}$

where:

$U_{c k}$ is the purchase intention of the $c$-th consumer for the $k$-th treatment with $c=1,2, \ldots, 144$ and $k=1,2, \ldots, 8 ; P W_{i j}$ is the part-worth associated with the -th level of the $j$-th attribute (with $n=5$ and $\left.m_{i}=2, \forall i\right) ; X_{i j}^{k}$ is the indicate variable ( $X_{i j}^{k}=0$ or $X_{i j}^{k}=1$ ) for the presence of the $j$ th level of the $i$ th attribute in the $k$ th treatment; and $\varepsilon_{c k}$ is the non-observable random error associated with the evaluation of the $k$-th treatment by the $c$-th consumer.

After defining the composition rule, the consumer data were submitted to conjoint analysis individually by estimating the part-worths for each consumer (MOORE, 1980).

\subsection{Simulating market share for the treatments}

The part-worths, previously estimated, were used in the market share simulation using the maximum utility model.

In the maximum utility model, for the $c$-th consumer, $p_{c k}=1$ if $\hat{U}_{c k}=\max _{k}\left(\hat{U}_{c k}\right)$, and $p_{c k}=0$ for the other treatments, where $p_{c k}$ is the purchase probability of the $k$-th product by the $c$-th consumer, and $\hat{U}_{c k}$ is the respective estimate of purchase intention.

A market share simulation of these treatments for the market segment composed of the 144 attendants of the 76th Farmer Week $\left(S M_{t}\right)$ was carried out.

The competitive scenario $\left(C C_{s}\right)$ was composed of all possible treatments $\left(n^{\mathrm{f}}=2^{5}=32\right.$ treatments), including those that were not evaluated by consumers in the conjoint analysis (Table 1).

The steps to determine the probability of purchase and market share $(M S)$ of the $k$-th treatment from the $s$-th 
Table 1. Market share simulation results.

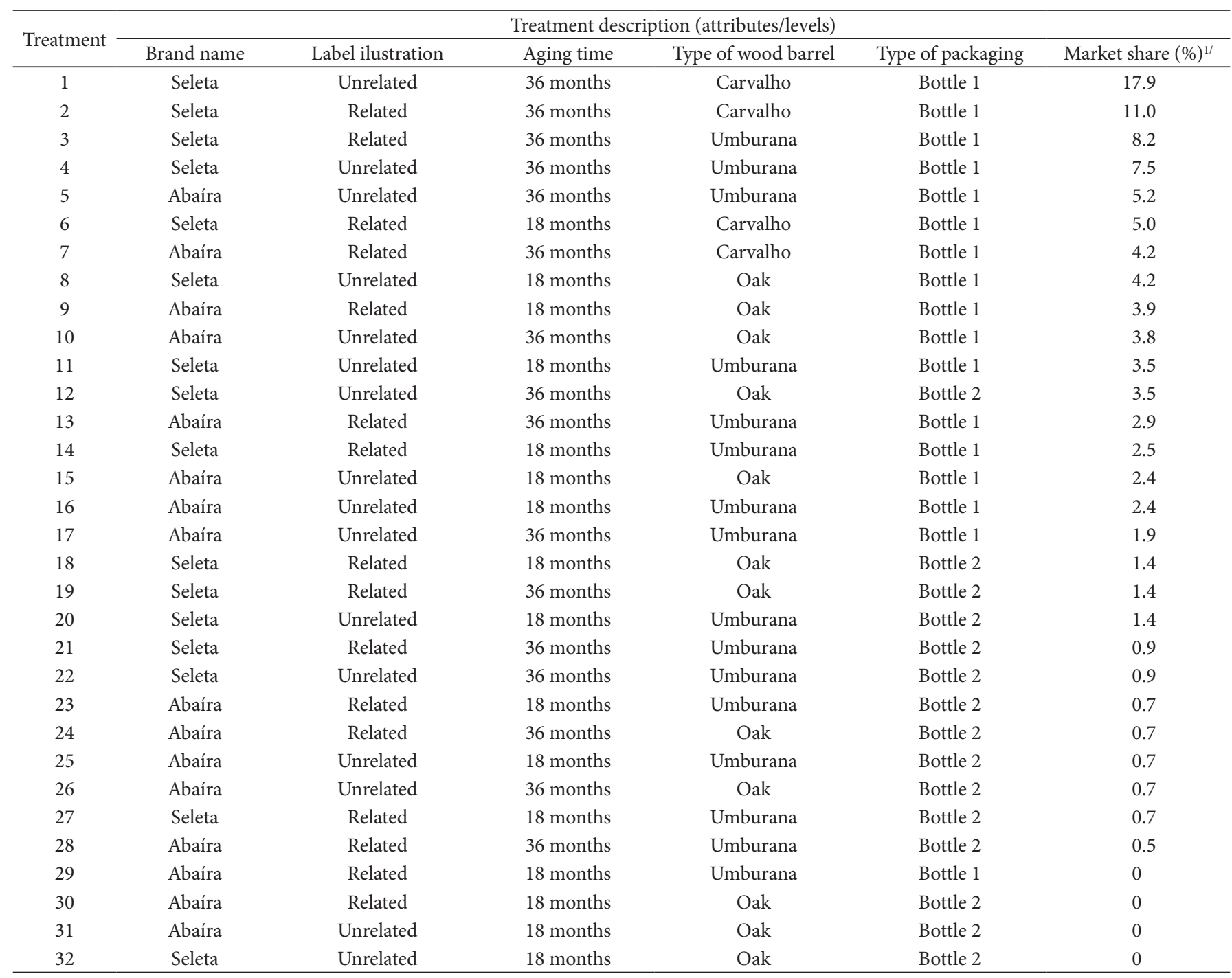

${ }^{1 /}$ Maximum utility model.

competitive scenario $\left(C C_{\mathrm{s}}\right)$ in the $t$-th market segment $\left(S M_{t}\right)$ were as follows:

- Estimation of the purchase intention for each treatment

Estimates of purchase intention were determined using the additive model as the composition rule (STEENKAMP, 1987). In this model, estimates of purchase intention are formed by the sum of the part-worths. The general form of the additive model for $\mathrm{n}$ factors, each one with $\mathrm{m}_{\mathrm{i}}$ levels, is given by:

$\hat{U}_{c k}\left(C C_{s}, S M_{t}\right)=\sum_{i=1}^{n} \sum_{j=1}^{m_{i}} P \hat{W}_{i j} X_{i j}^{k}$

$\hat{U}_{c k}\left(C C_{s}, S M_{t}\right)$ is estimate of purchase intention of $c$-th consumer $c$ in the $t$-th segment of the market, for the $k$-th treatment of the $s$-th competitive scenario; $P W_{\mathrm{ij}}$ is the part-worth estimated in the conjoint analysis associated with the $j$ th level of the $i$ th attribute (with $i=1,2, \ldots, 5$ and $j=1,2$ ).
$X_{i j}^{k}$ is the indicate variable $\left(X_{i j}^{k}=0\right.$ or $\left.X_{i j}^{k}=1\right)$ for the presence of the $j$ th level of the $i$ th attribute in the $k$-th treatment

For example, the estimate of purchase intention of consumer 1 in the market segment formed by the attendants of the $76^{\text {th }}$ Farmer Week for treatment 2 of the competitive scenario $s$ is:

$\hat{U}_{12}\left(C C_{s}, S M_{t}\right)=\sum_{i=1}^{5} \sum_{j=1}^{2} \hat{P W_{i j}} X_{i j}^{k}$

$\hat{U}_{12}\left(C C_{s}, S M_{t}\right)=\hat{P W}_{\text {Seleta }}+\hat{P W}_{\text {Related }}+\hat{P W}_{18 \text { months }}+\hat{P W}_{\text {oak }}+\hat{P W}_{\text {Botlel }}$

Therefore, the estimate of purchase intention for a given treatment is equal to the sum of the contributions of levels of the factors $\left(\hat{P W}_{s}\right)$ present in the composition of the respective treatment. 
- Estimation of the probability of purchase intention using the maximum utility model

The treatment $k$ of $C C_{s}$ with the highest estimate of purchase intention, i.e., the one that obtained $\underset{k}{\operatorname{maximum}} \hat{U}_{k c}\left(C C_{s}, S M_{t}\right)$ was identified for each consumer $c$ of the $S M_{t}$.

Next, the maximum utility model was applied, i.e., it was attributed purchase intention probability equal 1 to the treatment with the highest purchase intention estimate and probability equal zero to the other treatments.

\section{- Determination of market share (MS)}

The market share of each of the treatment $k$ of $C C_{s}$ in the $S M_{t}$ was calculated using the following formula:

$$
M S_{k}\left(C C_{s}, S M_{t}\right)=\frac{\sum_{c=1}^{144} p_{c k}\left(C C_{s}, S M_{t}\right)}{144}
$$

where $p_{c k}\left(C C_{s}, S M_{t}\right)$ if treatment $k$ has the maximum $\hat{U}_{c k}$ value for the $c$-th consumer and zero otherwise.

Statistical analyzes were performed using the software SAS, version 9.0, licensed for UFV (Federal University of Viçosa). The market share simulation was performed using a SAS macro (STATISTICAL..., 1993).

\section{Results and discussion}

\subsection{Conjoint analysis}

The part-worths were estimated using the conjoint analysis for 144 consumers. These coefficients were used in the market share simulation of the treatments.

\subsection{Market share simulation}

The results of the market share simulation performed for the market segment composed of the 144 attendants of the $76^{\text {th }}$ Farmer Week and 32 treatments of the competitive scenario are shown in Table 1.

Sugarcane spirits of brand Seleta that had on their label the information "aged for 36 months in oak barrels" and were packaged in $700 \mathrm{~mL}$ clear glass bottles with a metal screw cap (treatments 1 and 2) had the biggest market share (28.9\%). The second biggest share $(15.8 \%)$ belonged to the sugarcane spirits of brand Seleta that had on their label the information "aged for 36 months in umburana barrel" and were packaged $700 \mathrm{~mL}$ clear glass bottles with a with a metal screw cap. This shows that the attributes brand name, type of packaging, aging time, and type of wood barrel influenced consumer behavior in this market segment.

Another factor that influenced consumer behavior was the brand name. It was observed that the sugarcane spirits of brand Seleta accounted for $70.0 \%$ of the market, and those of the brand Abaíra accounted for $30.0 \%$. It is worth to mention that the brand Seleta is well known among the consumers in this market segment evaluated, while the brand Abaíra is little known. Therefore, the results show that the attendants of 76th Farmer Week preferred the well-known sugarcane spirit brands, i.e, the sugarcanes of brand Seleta were considered higher in quality than the brand Abaíra. Reis (2007), Della Lucia (2005), Carneiro (2002), Costa (2001) and Deliza (1996) also found that products of well-known brands were preferred by consumers confirming the result obtained.

It was also found that the sugarcane sprits containing the information "aged for 36 months in oak barrels" on the label had $43.2 \%$ of the market; those containing the information "aged for 36 months umburana barrel" had, 28.0\%; those containing the information "aged for 18 months in oak barrel" had 16.9\%; and those containing the information "aged for 18 months in umburana barrel" had $11.9 \%$. These results suggest that the attendees of the $76^{\text {th }}$ Farmer Week showed preference for sugarcane spirits that have on their label the information "aged for 36 months in oak barrel".

However, it is noteworthy that the sugarcane spirits that have on their label the information "aged for 18 months in oak barrel", "aged for 18 months in umburana barrel", and "aged for 36 months in umburana barrel" also had their market space. Hence, there was no unanimity among the consumers regarding the attributes type of wood barrel and aging time.

The treatments with label illustration related to the sugarcane spirit production process were responsible for $44.0 \%$ of the market, and those that bore labels unrelated with it were responsible for $56.0 \%$, showing that there are consumers who value both types of label illustrations.

The difference in market share between some pairs of treatments that differed in terms of the levels of a single attribute is shown in Table 2.

This comparison was made aiming to assess the influence of the attribute levels on the market share of the treatments.

It was observed that $700 \mathrm{~mL}$ clear glass bottles with a metal screw cap (bottle 1) had a positive influence on purchase intention of consumers and that $600 \mathrm{~mL}$ amber glass bottles with a metal crown cap (bottle 2 ) had a negative influence since comparing the market share of the pairs of treatments that differed in terms of type of packaging (pairs 1,2,3, and 4), it can be said that the bottle 1 contributes to an average increase of $9.5 \%$ in market share of the treatments. It was also observed that the changes in the type of packaging resulted in difference in the market share of pairs of treatments between $6.6 \%$ and $14.4 \%$, and that all sugarcane spirits packaged in bottle 1 had bigger market share than those packaged in bottle 2 .

Comparing the pairs of treatments in terms of brand name and aging time, it was found that the brand Seleta and the information "aged for 36 months" contributed to an average increase of about $7.0 \%$ in the market share of the treatments, suggesting that this information positively influenced consumer purchase intention.

It was observed that the information "aged in oak barrels" contributed to increase the market share in the pairs of treatments 13,14 , and 16 and reduce it in pair 15 . It was also noted that there was a difference of less than $2.8 \%$ in the average 
Table 2. Difference in market share pairs of treatments that differed in terms of the levels of a single attribute.

\begin{tabular}{|c|c|c|c|c|c|c|c|c|}
\hline \multirow{2}{*}{ Pairs } & \multicolumn{8}{|c|}{ Treatment description (attributes/levels) } \\
\hline & Brand name & Label illustration & Aging time & Type of wood barrel & Type of packaging & Market share (\%) & Difference (\%) & Average $(\%)^{1 /}$ \\
\hline \multicolumn{9}{|c|}{ Pairs of treatments that differed in terms of type of packaging } \\
\hline \multirow[t]{2}{*}{1} & Seleta & Unrelated & 36 months & Oak & Bottle 1 & 17.9 & 14.4 & 9.5 \\
\hline & Seleta & Unrelated & 36 months & Oak & Bottle 2 & 3.5 & & \\
\hline \multirow[t]{2}{*}{2} & Seleta & Related & 36 months & Oak & Bottle 1 & 11.0 & 9.6 & \\
\hline & Seleta & Related & 36 months & Oak & Bottle 2 & 1.4 & & \\
\hline \multirow[t]{2}{*}{4} & Seleta & Unrelated & 36 months & Umburana & Bottle 1 & 7.5 & 6.6 & \\
\hline & Seleta & Unrelated & 36 months & Umburana & Bottle 2 & 0.9 & & \\
\hline \multicolumn{9}{|c|}{ Pairs of treatments that differed in terms of brand name } \\
\hline \multirow[t]{2}{*}{5} & Seleta & Unrelated & 36 months & Oak & Bottle1 & 17.9 & 14.1 & 7.1 \\
\hline & Abaíra & Unrelated & 36 months & Oak & Bottle1 & 3.8 & & \\
\hline 7 & Abaíra & Related & 36 months & Umburana & Bottle1 & 2.9 & & \\
\hline \multirow[t]{2}{*}{8} & Seleta & Unrelated & 36 months & Umburana & Bottle1 & 7.5 & 2.3 & \\
\hline & Abaíra & Unrelated & 36 months & Umburana & Bottle1 & 5.2 & & \\
\hline \multicolumn{9}{|c|}{ Pairs of treatments that differed in terms of aging time } \\
\hline \multirow[t]{2}{*}{9} & Seleta & Unrelated & 36 months & Oak & Bottle1 & 17.9 & 13.7 & 7.4 \\
\hline & Seleta & Unrelated & 18 months & Oak & Bottle1 & 4.2 & & \\
\hline \multirow[t]{2}{*}{10} & Seleta & Related & 36 months & Oak & Bottle1 & 11.0 & 6.0 & \\
\hline & Seleta & Related & 18 months & Oak & Bottle1 & 5.0 & & \\
\hline \multirow[t]{2}{*}{11} & Seleta & Related & 36 months & Umburana & Bottle1 & 8.2 & 5.7 & \\
\hline & Seleta & Related & 18 months & Umburana & Bottle1 & 2.5 & & \\
\hline 12 & Seleta & Unrelated & 36 months & Umburana & Bottle1 & 7.5 & 4.0 & \\
\hline 15 & Abaíra & Unrelated & 36 months & Umburana & Bottle1 & 5.2 & & \\
\hline 16 & Seleta & Related & 18 months & Oak & Bottle1 & 5.0 & 2.5 & \\
\hline & Seleta & Related & 18 months & Umburana & Bottle1 & 2.5 & & \\
\hline Pairs C & f treatments & that differed in ter & ns of label ill & istration & & & & \\
\hline 17 & Seleta & Related & 36 months & Oak & Bottle1 & 11.0 & 6.9 & 2.7 \\
\hline & Seleta & Unrelated & 36 months & Oak & Bottle1 & 17.9 & & \\
\hline 18 & Seleta & Related & 36 months & Umburana & Bottle1 & 8.2 & 0.7 & \\
\hline & Seleta & Unrelated & 36 months & Umburana & Bottle1 & 7.5 & & \\
\hline 19 & Abaíra & Related & 36 months & Umburana & Bottle1 & 2.9 & 2.3 & \\
\hline & Abaíra & Unrelated & 36 months & Umburana & Bottle1 & 5.2 & & \\
\hline 20 & Seleta & Related & 18 months & Oak & Bottle1 & 5.0 & 0.8 & \\
\hline & Seleta & Unrelated & 18 months & Oak & Bottle1 & 4.2 & & \\
\hline
\end{tabular}

${ }^{1 / A v e r a g e ~ d i f f e r e n c e ~ o f ~ t h e ~ f o u r ~ p a i r s ~ o f ~ t r e a t m e n t s . ~}$

market share in the pairs of treatments when the information about the type of wood was changed.

As for the label illustration attribute, there was the average difference of $2.7 \%$ in the market share of the treatments that differed only in terms to this attribute. The illustration related to sugarcane spirit production process contributed to reduce the market share of the treatments.

It was found that the attributes studied influenced the behavior of consumer in this market segment and influenced the market share of the treatments. These consumers preferred 
the sugarcane spirit of brand Seleta, packaged in $700 \mathrm{~mL}$ clear glass bottles with a metal screw cap, containing the label illustration unrelated to sugarcane production process, and with the information "aged for 36 months in oak barrels".

It is noteworthy to mention that this is the first study that evaluated the influence of packaging and labeling attributes on sugarcane consumers' behavior. This fact shows the relevance of this study, but it hinders the comparison of the results.

\section{Conclusions}

It was observed that the attributes type of packaging and label illustration influenced the purchase intention of consumers, and that the consumers showed similar preference in relation to the attributes studied. These consumers preferred the sugarcane spirit of brand Seleta, packaged in $700 \mathrm{~mL}$ clear glass bottles with a metal screw cap, containing the label illustration unrelated to sugarcane production process, and with the information "aged for 36 months in oak barrels".

It is also found that the conjoint analysis and the application of its results in the market share simulation were useful tools to understand the behavior of sugarcane spirit consumers.

The results obtained in this study will help sugarcane spirit producers to design, change, and choose packages and labels, choose type of wood barrel to age the spirit, and determine the aging time. These findings will also contribute to the development of effective marketing strategies, which will help increase the competitiveness of the sugarcane spirit market.

\section{Acknowledgements}

The authors are grateful for the financial support provided by FAPESB (The State of Bahia Research Foundation) and to scholarship granted by $\mathrm{CNPq}$ (The National Council for Scientific and Technological Development.

\section{References}

ABREU-LIMA, T. L.; MAIA, A. B. R.; OLIVEIRA, E. E. Efeitos sensoriais da adição de extratos de diferentes madeiras à cachaça. Boletim do CEPPA, v. 23, n. 2, p. 347-360, 2005.

AGUIAR, P. M. Aspectos físico-químicos de cachaças armazenadas em tonéis de carvalho. 2003. 73 f. Tese (Mestrado em Agronomia)Universidade Federal de Lavras, Lavras, 2003.

ASSOCIAÇÃO BRASILEIRA DE BEBIDAS - ABRABE. Disponível em: <http://www.abrabe.org.br>. Acesso em: jan. 2012.

CANTÃO, F. O. Análises físico-químicas e avaliação da presença de cobre em aguardente de cana por aluminossilicatos. 2006. $62 \mathrm{f}$. Tese (Mestrado em Agronomia)-Universidade Federal de Lavras, Lavras, 2002.

CARDELLO, H. M. A. B.; FARIA, J. B. Análise da aceitação de aguardentes de cana por teste afetivos e mapa de preferência interno. Ciência e Tecnologia de Alimentos, v. 20, n. 1, p. 32-36, 2000. http:// dx.doi.org/10.1590/S0101-20612000000100007

CARDELLO, H. M. A. B.; FARIA, J. B. Análise descritiva quantitativa da aguardente de cana durante o envelhecimento em tonel de carvalho (Quercus alba L.). Ciência e Tecnologia de Alimentos, v. 18 , n. 2, p. 169-175, 1998. http://dx.doi.org/10.1590/S010120611998000200005

CARNEIRO, J. D. S.; SILVA, C. H. O.; MINIM, V. P. R. Análise conjunta de fatores. In: MINIM, V. P. R. (Ed.). Análise sensorial: estudos com consumidores. 2nd. ed. Viçosa: Editora UFV, 2010. cap. 7, p. $169-213$.

CARNEIRO, J. D. S. Impacto da embalagem de óleo de soja na intenção de compra do consumidor, via conjoint analysis. 2002. $80 \mathrm{f}$. Tese (Mestrado em Ciência e Tecnologia de Alimentos)-Universidade Federal de Viçosa, Viçosa, 2002.

COSTA, M. C. Tecnologias não convencionais e o impacto no comportamento do consumidor. 1999. 119 f. Tese (Mestrado em Ciência e Tecnologia de Alimentos)-Universidade Federal Rural do Rio de Janeiro, Rio de Janeiro, 1999.

DANTAS, M. I. S. Impacto da embalagem de couve (Brassica oleraceal cv. acephala) minimamente processada na intenção de compra do consumidor. 2001. 77 f. Tese (Mestrado em Ciência e Tecnologia de Alimtentos)-Universidade Federal de Viçosa, Viçosa-MG.

DELIZA, R. The effects of expectation on sensory perception and acceptance. 1996. 198 f. Thesis (Doctorate)-University of Reading, Reading, 1996.

DELIZA, R. et al. Consumer Perception of Irradiated Fruit: a Case Study Using Choice-Based Conjoint Analysis. Journal of Sensory Studies, v. 25, n. 2, p. 184-200, 2010. http://dx.doi.org/10.1111/ j.1745-459X.2009.00250.x

DELLA LUCIA, S. M. Conjoint analysis no estudo de mercado de café orgânico. 2005. 86 f. Tese (Mestrado em Ciência e Tecnologia de Alimentos)-Universidade Federal de Viçosa, Viçosa, 2005.

DELLA LUCIA, S. M. et al. Análise conjunta de fatores baseada em escolhas no estudo da embalagem de iogurte light sabor morango. Brazilian Journal of Food Technology, v. 14, p. 11-18, 2011. http:// dx.doi.org/10.4260/BJFT201114E000102

FARIA, J. B. et al. Evaluation of Brazilian woods as an alternative to oak for cachaças aging. Food Research Technology, v. 218, p. 83-87, 2003. http://dx.doi.org/10.1007/s00217-003-0795-Z

FURTADO, S. M. B. Avaliação sensorial descritiva de aguardente de cana e influência da composição em suas características sensoriais e correlação entre medidas sensoriais e físico-químicas. 1995. $62 \mathrm{f}$. Tese (Doutorado em Tecnologia de Alimentos)-Faculdade de Engenharia de Alimentos, Campinas, 1995.

GREEN, P. E.; SRINIVASAN, V. Conjoint analysis in consumer research: issues and outlook. Journal of Consumer Research, v. 5, p. 103-123, 1978.

HAIR JUNIOR, J. F. et al. Multivariate Data Analysis. 5th ed. New Jersey: Prentice Hall, 1998.

JERONIMO, E. M.; CARDELlO, H. M. A. B.; SERRA, G. E. Perfil sensorial de aguardente de cana em função da diluição e variação da acidez da amostra. Boletim do CEPPA, v. 22, n. 1, p. 51-64, 2004.

KIMURA, A. et al. Conjoint Analysis on the Purchase Intent for Traditional Fermented Soy Product (Natto) among Japanese Housewives. Journal of Food Science, v. 76, n. 3, p. 217-224, 2011. http://dx.doi.org/10.1111/j.1750-3841.2011.02047.x

LIMA, A. J. B. Avaliação do emprego de substâncias adsorventes na melhoria da qualidade de cachaça com excesso de cobre. 2005. $64 \mathrm{f}$. Tese (Mestrado em Agronomia)-Universidade Federal de Lavras, Lavras, 2005.

MacFIE, H. J. et al. Designs to balance the effect of order of presentation and first-order carry-over effects in hall tests. Journal of Sensory 
Studies, v. 4, p. 129-148, 1989. http://dx.doi.org/10.1111/j.1745459X.1989.tb00463.x

MESIAS, F. et al. Functional and organic eggs as an alternative to conventional production: a conjoint analysis of consumers' preferences. Journal of the Science of Food and Agriculture, v. 91, n. 3, p. 532-538, 2011. http://dx.doi.org/10.1002/jsfa.4217

MILLHER, J. T.; OGDEN, J. R.; LATSHAW, C. A. Using trade-off analysis to determine value-price sensitivily of custom calling features. American Business Review, v. 16, n. 1, p. 8-13, 1998.

MOORE, W. L. Leves of aggregation in conjoint analysis: an empirical comparison. Journal of Marketing Research, v. 18, p. 516-523, 1980.

MORI, F. A. et al. Utilização de eucaliptos e de madeiras nativas no armazenamento da aguardente de cana-de-açúcar. Ciência e Tecnologia de Alimentos, v. 23, n. 3, p. 396-400, 2003. http://dx.doi. org/10.1590/S0101-20612003000300018

OLIVEIRA, E. R. A “marvada pinga” - produção de cachaça e desenvolvimento em Salinas, Norte de Minas Gerais. 2000. $178 \mathrm{f}$. Tese (Mestrado em Administração Rural e Desenvolvimento)Universidade Federal de Lavras, Lavras, 2000.

REIS, R. C. Iogurte "light" sabor morango: equivalência de doçura, caracterização sensorial e impacto da embalagem na intenção de compra do consumidor. 2007. 143 f. Dissertação (Doutorado em
Ciências e Tecnologia de Alimentos)-Universidade Federal de Viçosa, Viçosa, 2007.

STATISTICAL ANALISYS SYSTEM INSTITUTE - SAS. Conjoint Analysis Examples. Cary: SAS Institute Inc., 1993. 85 p. SAS Technical Report R-109.

SOUZA, E. A. M. et al. O efeito da embalagem na intenção de compra do consumidor. In: ENCONTRO NACIONAL SOBRE PROCESSAMENTO MÍNIMO DE FRUTAS E HORTALIÇAS, 3., 2004, Viçosa. Palestras, Resumos e Oficinas.... Viçosa: Universidade Federal de Viçosa, 2004.

STEENKAMP, J-B. E. M. Conjoint measurement in ham quality evalution. Journal Agricultural Economies, v. 38, n. 3, p. 473-480, 1987.

YOKOTA, S. R. C. Qualidade sensorial e físico-química de cachaças envelhecidas em recipientes de carvalho e de algumas madeiras brasileiras. 2002. 140 f. Dissertação (Mestrado em Ciência e Tecnologia de Alimtentos)-Universidade Federal de Viçosa, Viçosa, 2002.

YOKOTA, S. R. C. Avaliação sensorial descritiva de cachaça envelhecida por 18 e 24 meses: contribuição para um protocolo de qualidade da bebida. 2005. $104 \mathrm{f}$. Tese (Doutorado em Ciência e Tecnologia de Alimentos)-Universidade Federal de Viçosa, Viçosa, 2005. 